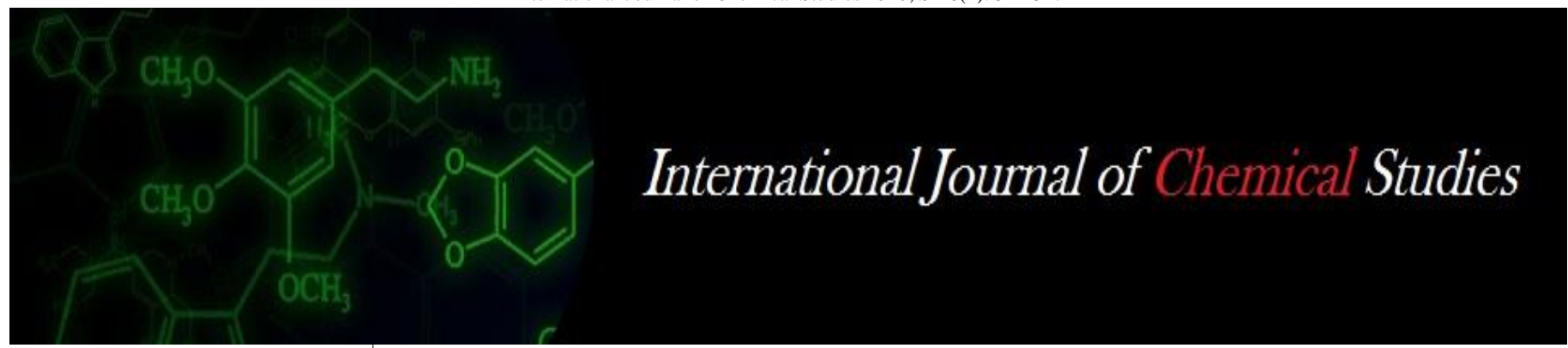

P-ISSN: 2349-8528

E-ISSN: 2321-4902

www.chemijournal.com

IJCS 2020; SP-8(4): 344-347

(C) 2020 IJCS

Received: 18-05-2020

Accepted: 20-06-2020

Karukonda Giridhar

M.Sc. Student, MSSSoA

Centurion University of

Technology and Management

Paralakhemundi, Odisha, India

Pakalpati Satyanarayana Raju Professor Emeritus, MSSSoA,

Centurion University of

Technology and Management

Paralakhemundi, Odisha, India

Ganesh Pushpalatha

Associate Professor, MSSSoA,

Centurion University of

Technology and Management

Paralakhemundi, Odisha, India

Chinmayee Patra

Assistant Professor, MSSSoA,

Centurion University of

Technology and Management

Paralakhemundi, Odisha, India

Corresponding Author: Ganesh Pushpalatha

Associate Professor, MSSSoA,

Centurion University of

Technology and Management

Paralakhemundi, Odisha, India

\section{Effects of plant density on yield parameters of cowpea (Vigna unguiculata $\mathbf{L}$.)}

\section{Karukonda Giridhar, Pakalpati Satyanarayana Raju, Ganesh Pushpalatha and Chinmayee Patra}

DOI: $\underline{\text { https://doi.org/10.22271/chemi.2020.v8.i4f.10090 }}$

\begin{abstract}
Cowpea (Vigna unguiculata L.) is an important pulse, fodder and green manure crop. In symbiotic association with Rhizobium bacteria, cowpea fixes atmospheric dinitrogen in its root nodules. Hence cowpea forms an integral part of the cropping systems in Indian agriculture. A field experiment was

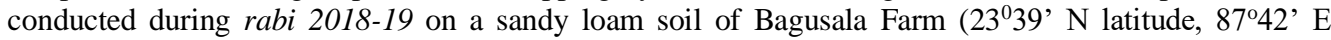
longitude), M. S. Swaminathan School of Agriculture, Gajapati District, Odisha, to study the effects of variety, plant spacing and variety $\mathrm{x}$ spacing interaction on the yield components of cowpea. The experiment was conducted in a split plot design with three replications. Three cowpea varieties, Ketaki, Kamini, and Gomati, were the main plots and three within row plant spacings of 10,15 and $20 \mathrm{~cm}$, corresponding to plant population densities of 333333, 222222 and 166666 plants ha $^{-1}$, were the split plots, forming a total of nine treatment combinations. The seeds of cowpea were sown in rows on ridges spaced $30 \mathrm{~cm}$ apart. At harvest the yield attributes, pod length, pods plant ${ }^{-1}$, grain yield, 100 grain weight, biological yield, stover yield and harvest index were recorded. The three cowpea varieties tested did not differ significantly in pods plant ${ }^{-1}$ and pod length but differed in 100 grain test weight. Gomati had the highest grain test weight, followed by Ketaki, with Kamini having the least test weight. Higher grain yield was recorded in the widest spacing of $20 \mathrm{~cm}$ compared to the closest spacing of $10 \mathrm{~cm}$. Cowpea varieties, plant spacings and variety $\mathrm{x}$ spacing interactions did not have significant effects on stover yields and harvest indices. The widest plant spacing of $20 \mathrm{~cm}$ had higher benefit-cost ratio (BC ratio) than the closer spacings of 10 and $15 \mathrm{~cm}$ which had similar BC ratios. Variety x spacing interactions affected $\mathrm{BC}$ ratio.
\end{abstract}

Keywords: Cowpea, grain yield, harvest index, plant spacing, population density, stover

\section{Introduction}

Highlights

- Higher grain yield was recorded in the widest spacing of $20 \mathrm{~cm}$ compared to the closest spacing of $10 \mathrm{~cm}$.

- The widest plant spacing of $20 \mathrm{~cm}$ had higher benefit-cost ratio than the closer spacing of 10 and $15 \mathrm{~cm}$ which had similar BC ratios.

Pulses are important sources of proteins, vitamins, and minerals for the predominantly vegetarian population of India. Besides, pulse crops fix dinitrogen of the atmosphere in their root nodules in symbiotic association with Rhizobia bacteria and enrich soil fertility. Therefore, they form an integral part of the cropping systems in Indian agriculture. India is the largest producer and consumer of pulses in the world. The production of pulses in India is 25.23 million tones and the projected demand by the year 2030 is 35 million tonnes (Farmer Portal, 2018) ${ }^{[2]}$. Pulse production in India is not commensurate with the demand in the country. There has been stagnation in the production and productivity of pulses over the past three decades. This is mainly due to the low yield potential of legumes under irrigation, instability of yields and diversion of acreage from pulses to cereals.

The important grain legumes grown in India are bengalgram, lentil, greengram, blackgram, cowpea, redgram and peas. Among grain legumes, cowpea (Vigna unguiculata L.) is an important crop in the arid and semi-arid tropical regions. The green pods of cowpea are used as vegetable. In addition to grain, it is also grown for its nutritious fodder. Cowpea is grown as 
catch crop, mulch crop, intercrop, mixed crop and green manure crop. It has the ability to fix atmospheric nitrogen in soil at the rate of $56 \mathrm{~kg}$ per ha in association with symbiotic bacteria under favorable conditions (Yadav, 2003) ${ }^{[8]}$. Cowpea is often grown as a green manure crop for soil improvement. The crop has rapid and luxuriant vegetative growth and covers the ground so well that it checks soil erosion and also weeds and can later be ploughed into the soil as green manure. It has considerable promise as a pulse crop in dry land farming and sustainable agriculture.

Cowpea is a warm weather crop grown and is grown in the semi-arid tropics. Day temperature of $27^{\circ} \mathrm{C}$ and night temperature of $22^{\circ} \mathrm{C}$ are considered optimum for cowpea cultivation. In India, cowpea is grown in an area of 3.9 million ha with a production of 2.21 million tonnes. In Odisha, the crop is grown in an area of 1.5 million ha with a production of 0.49 million tonnes. The productivity of cowpea in Odisha is low $(420 \mathrm{~kg} / \mathrm{ha})$ compared to the national productivity of $567 \mathrm{~kg} \mathrm{ha}^{-1}$. This clearly indicates the necessity for research to improve cowpea productivity in India in general and Odisha in particular.

Plant population density is a key factor affecting growth and yield of crops. High population densities may affect light interception, nutrient uptake and water availability of crops. Optimum population densities for different crop varieties need to be determined in different agroclimatic zones and soil types to improve crop productivity. It is the most important non-monetary input, which can be manipulated to attain maximum production per unit area. The present study was undertaken during the rabi season of 2018-19 to study the effects of intra-row spacing on the yield components of three cowpea varieties and to determine the optimum plant population densities for the cowpea varieties to maximize grain yield on sandy loam soils in Gajapati District of Odisha.

\section{Materials and methods \\ Experiment Site and Design}

A field experiment was conducted during rabi season of 2018-19 in the Instructional Farm of Centurion University,

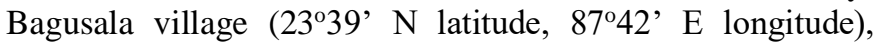
Gajapati district, Odisha, under typical sub-humid and subtropical climatic conditions. The soil was a sandy loam, where the percentages of sand, silt and clay were 55.2, 20.4 and 18.5 , respectively. The soil $\mathrm{pH}$ was 6.2 , EC $0.35 \mathrm{dS} \mathrm{m}^{-1}$ and organic carbon $0.31 \%$. During the period of experimentation, the minimum and maximum temperature ranged from $18^{\circ} \mathrm{C}$ and $35^{\circ} \mathrm{C}$, respectively and the crop received rainfall of 16.36 , 4.43 and $0.08 \mathrm{~mm}$ during the months of December, January and February, respectively.

The experiment was conducted in a split plot design with three replications. Three cowpea varieties, Ketaki, Kamini and Gomati, were the main plots and three within row plant spacings of 10,15 and $20 \mathrm{~cm}$, corresponding to plant population densities of 333333, 222222 and 166666 plants ha $^{-}$ 1 , were the split plots, forming a total of nine treatment combinations. The seeds of cowpea were sown in rows on ridges spaced $30 \mathrm{~cm}$ apart. Each plot consisted of 10 rows, each $3 \mathrm{~m}$ long and an area of $9 \mathrm{~m}^{2}$.

\section{Experiment procedure}

The land was prepared by ploughing twice with a mouldboard plough and then harrowing, levelling and ridging. Basal fertilizer was applied at the rate of $25 \mathrm{~kg} \mathrm{~N}, 50 \mathrm{~kg} \mathrm{P}_{2} \mathrm{O}_{5}$ and $25 \mathrm{~kg} \mathrm{~K}_{2} \mathrm{O} \mathrm{ha}^{-1}$ in the form of urea, single super phosphate and muriate of potash, respectively. The cowpea seeds of the varieties, Ketaki, Kamini and Gomati were sown on $8^{\text {th }}$ December, 2018 and the field irrigated. Seeds were sown in rows spaced at $30 \mathrm{~cm}$ at a depth of $4 \mathrm{~cm}$. Three seeds were sown per hill at spacings of 10,15 and $20 \mathrm{~cm}$. Irrigations were applied thereafter when needed. Gap filling was undertaken one week after sowing and thinning was done 15 days after sowing (DAS), retaining one healthy seedling per hill, to maintain desired plant population treatments. Two hand weedings were done at 15 and 30 DAS. The plants were harvested after physiological maturity, when the pods turned yellow, by cutting the plants at ground level. Five randomly selected plants from each plot were harvested separately for yield component analysis. Statistical analysis of the data recorded for various yield attributes was done using statistical procedures appropriate for the split plot design and the variety, spacing, and vatiety $\mathrm{x}$ spacing interaction variances were tested by the " $F$ " test. Treatment means, standard errors of means, co-efficient of variation percentages and critical differences (CDs) at 5\% probability level were calculated and the obtained $\mathrm{CD}$ values compared with table values to test whether the various yield components showed significant differences amongst treatments.

\section{Observations on yield attributes}

At harvest, five pods were collected at random from five randomly selected plants from each treatment combination and their lengths measured in $\mathrm{cm}$ with a measuring scale. The filled pods of the selected plants were counted and the mean pods plant ${ }^{-1}$ calculated. Random grain samples were drawn from the threshed and cleaned produce from each plot and weights of 100 grains were recorded. The harvest produce from each net plot was tied separately into bundles. The bundles were sun dried for 2 days and weighed with the help of a spring balance. Later, the value of the biological yield of each plot was converted to $\mathrm{kg} \mathrm{ha}^{-1}$. After picking, threshing and winnowing, the grain yield of each plot was weighed and recorded in $\mathrm{kg}$. The plot yield was later converted to $\mathrm{kg} / \mathrm{ha}^{-1}$. The crop bundle of each plot was weighed and recorded as per treatment in $\mathrm{kg}$ and thereafter the stover yield was calculated by subtracting the grain yield from the biological yield. The results were expressed in $\mathrm{kg} / \mathrm{ha}^{-1}$. Harvest index was calculated as the ratio of economic yield to the biological yield and multiplied by 100 to obtain the value as percentage.

\section{Results and discussion}

The three cowpea varieties tested did not differ significantly in pods plant ${ }^{-1}$ and pod length but differed in 100 grain test weight (Table 1). Gomati had the highest grain test weight, followed by Ketaki, with Kamini having the least test weight. Plant spacing affected pods plant ${ }^{-1}$ and pod length. The wider spacing of $20 \mathrm{~cm}$ resulted in more pods plant ${ }^{-1}$ and longer pods than the closer spacing of $10 \mathrm{~cm}$. Varieties did not differ significantly for pods plant ${ }^{-1}$ and pod length in each spacing treatment. However, spacing affected pods plant $^{-1}$ and pod length of each variety, with all varieties having the highest pod numbers and pod lengths in the widest spacing of $20 \mathrm{~cm}$ and least pod numbers and pod lengths in the closest spacing of $10 \mathrm{~cm}$.

The grain test weight differed significantly between the three cowpea varieties (Table 1). Gomati recorded the highest test weight, followed by Ketaki, with Kamini recording the least test weight. Plant spacing too significantly affected test weight, with the widest spacing of $20 \mathrm{~cm}$ recording the highest test weight, followed by $15 \mathrm{~cm}$ spacing, and the closest spacing of $10 \mathrm{~cm}$ recording the lowest test weight. 
Variety x spacing interaction affected 100 grain test weights. The variety Gomati did not differ significantly from Ketaki but had higher test weight than Kamini in 10 and $15 \mathrm{~cm}$ plant spacings. At the widest spacing of $20 \mathrm{~cm}$, Gomati recorded the highest test weight, followed by Ketaki, with Kamini recording the least test weight. Each variety showed significant differences in test weight at different plant spacings. The test weight of each variety increased with increase in plant spacing, with highest for each variety being in the widest spacing of $20 \mathrm{~cm}$ and the least in the closest spacing of $10 \mathrm{~cm}$.

Plants with wider spacing of $20 \mathrm{~cm}$ had more pods plant ${ }^{-1}$, longer pods and greater 100 grain test weight than plants with closer spacing of $10 \mathrm{~cm}$. This may be due to less competition for light, moisture and nutrients associated with wider spacing and thereby having an edge in producing more reproductive parts when compared to higher plant population density. These results are in conformity with finding of Rajesh Kumar et al. (1997) ${ }^{[5]}$ and Shiva Kumar et al. (2002) ${ }^{[6]}$. The grain test weight differed significantly between the three cowpea varieties (Table 1). Gomati recorded the highest test weight, followed by Ketaki, with Kamini recording the least test weight. Plant spacing too significantly affected test weight, with the widest spacing of $20 \mathrm{~cm}$ recording the highest test weight, followed by $15 \mathrm{~cm}$ spacing and the closest spacing of $10 \mathrm{~cm}$ recording the lowest test weight. Variety $\mathrm{x}$ spacing interaction affected 100 grain test weights. The variety Gomati did not differ significantly from Ketaki but had higher test weight than Kamini in 10 and $15 \mathrm{~cm}$ plant spacings. At the widest spacing of $20 \mathrm{~cm}$, Gomati recorded the highest test weight, followed by Ketaki, with Kamini recording the least test weight. Each variety showed significant differences in test weight at different plant spacings. The test weight of each variety increased with increase in plant spacing, with highest for each variety being in the widest spacing of $20 \mathrm{~cm}$ and the least in the closest spacing of $10 \mathrm{~cm}$.

Plants with wider spacing of $20 \mathrm{~cm}$ had more pods plant ${ }^{-1}$, longer pods and greater 100 grain test weight than plants with closer spacing of $10 \mathrm{~cm}$. This may be due to less competition for light, moisture, and nutrients associated with wider spacing and thereby having an edge in producing more reproductive parts when compared to higher plant population density. These results are in conformity with finding of
Rajesh Kumar et al. (1997) ${ }^{[5]}$ and Shiva Kumar et al. (2002) [6]

Grain yield ha-1 did not differ significantly among varieties (Table 2). The within-row plant spacings affected grain yields significantly. Higher grain yield was recorded in the widest spacing of $20 \mathrm{~cm}$ compared to the closest spacing of $10 \mathrm{~cm}$. Interaction effects of variety $\mathrm{x}$ spacing were found to be not significant. The variations in grain yield components may be attributed to varietal differences and variations due to plant population densities. The rate of dry matter accumulation in reproductive parts (pods) indicates the efficiency of a genotype. Similar findings were also recorded by Arnon (1975) [1] and Natarajaratnam (1979) ${ }^{[4]}$. Further, less competition for light, moisture and nutrients associated with wider spacing had an edge in producing more reproductive parts compared to higher plant density. Similar findings were also reported by Manjappa (1994) ${ }^{[3]}$. Cowpea varieties, plant spacings and variety $\mathrm{x}$ spacing interactions did not have significant effects on stover yields and also harvest indices (Tables 2 and 3). However, the high stover yields indicate luxuriant vegetative growth of the three cowpea varieties. Cowpea stover has high nutritive value and provides valuable fodder to cattle. The moderate harvest indices ranging from 27.4 to $34.9 \%$ indicate the moderate efficiency of the cowpea varieties in diversion of photosynthates and nutrients to the grains.

The three cowpea varieties did not show significant differences in benefit-cost ratio (BC ratio) (Table 3 ). The widest plant spacing of $20 \mathrm{~cm}$ had higher $\mathrm{BC}$ ratio than the closer spacings of 10 and $15 \mathrm{~cm}$ which had similar BC ratios. Variety $x$ spacing interactions affected $B C$ ratio. Varieties did not differ in $\mathrm{BC}$ ratio in each spacing treatment. However, $\mathrm{BC}$ ratio of each variety was significantly affected by plant spacing. All varieties had the highest $\mathrm{BC}$ ratio in the widest plant spacing of $20 \mathrm{~cm}$ and lower and similar $\mathrm{BC}$ ratios in the two closer spacings of 10 and $15 \mathrm{~cm}$. Economics is a major criterion to evaluate treatments which are economically sound and that can be accepted by the farming community. In the present study, the maximum $\mathrm{BC}$ ratios were realized by all the varieties at the wider plant spacing of $20 \mathrm{~cm}$ compared to the closer spacings of 10 and $15 \mathrm{~cm}$. These findings were in conformity with those of Shivananda (2005) ${ }^{[7]}$.

Table 1: Pods plant ${ }^{-1}$, pod length and 100 grain test weight of cowpea varieties at plant spacings of 10,15 and $20 \mathrm{~cm}$

\begin{tabular}{|c|c|c|c|c|c|c|c|c|c|c|c|c|}
\hline \multicolumn{5}{|c|}{ Pods plant $^{-1}$} & \multicolumn{4}{|c|}{ Pod length $(\mathrm{cm})$} & \multicolumn{4}{|c|}{ Test weight (g) } \\
\hline \multicolumn{5}{|c|}{ Spacing } & \multicolumn{4}{|c|}{ Spacing } & \multicolumn{4}{|c|}{ Spacing } \\
\hline Variety & $10 \mathrm{~cm}$ & $15 \mathrm{~cm}$ & $20 \mathrm{~cm}$ & Mean & $10 \mathrm{~cm}$ & $15 \mathrm{~cm}$ & $20 \mathrm{~cm}$ & Mean & $10 \mathrm{~cm}$ & $15 \mathrm{~cm}$ & $20 \mathrm{~cm}$ & Mean \\
\hline Kamini & 8.6 & 9.1 & 11.5 & 9.7 & 25.9 & 27.3 & 28.7 & 27.3 & 50.6 & 51.2 & 52.5 & 51.4 \\
\hline Ketaki & 8.7 & 10.3 & 12.3 & 10.4 & 25.9 & 27.4 & 28.8 & 27.6 & 50.8 & 51.5 & 52.9 & 51.7 \\
\hline Gomati & 9.9 & 11.3 & 13.5 & 11.6 & 26.6 & 27.6 & 29.1 & 27.8 & 51 & 51.5 & 53.2 & 51.9 \\
\hline \multirow[t]{2}{*}{ Mean } & 9.0 & 10.2 & 12.4 & & 26.3 & 27.4 & 28.8 & & 50.8 & 51.4 & 52.8 & \\
\hline & & SEM & $\mathrm{CD}(\mathrm{P} \leq 0.05)$ & & & SEM & $\mathrm{CD}(\mathrm{P} \leq 0.05)$ & & & SEM & $\mathrm{CD}(\mathrm{P} \leq 0.05)$ & \\
\hline $\mathrm{V}$ & & 0.79 & 3.08 & & & 0.69 & 2.73 & & & 0.04 & 0.17 & \\
\hline $\mathrm{S}$ & & 0.40 & 1.23 & & & 0.48 & 1.48 & & & 0.03 & 0.10 & \\
\hline \multicolumn{13}{|c|}{\begin{tabular}{|l|l|}
$\mathrm{VxS}$ & \\
\end{tabular}} \\
\hline \multicolumn{2}{|c|}{$\mathrm{V}$ at same level of $\mathrm{S}$} & 0.97 & 3.51 & & & 0.98 & 3.41 & & & 0.07 & 0.22 & \\
\hline \multicolumn{2}{|c|}{$\mathrm{S}$ at same level of $\mathrm{V}$} & 0.69 & 2.12 & & & 0.84 & 2.56 & & & 0.06 & 0.18 & \\
\hline
\end{tabular}

Table 2: Grain and stover yields $\left(\mathrm{kg} \mathrm{ha}^{-1}\right)$ of cowpea varieties at plant spacings of 10, 15 and $20 \mathrm{~cm}$

\begin{tabular}{|c|c|c|c|c|c|c|c|c|}
\hline \multicolumn{4}{|c|}{ Grain yield $\left(\mathbf{k g ~ h a}^{-\mathbf{1}}\right)$} & \multicolumn{5}{c|}{ Stover yield $\left(\mathbf{k g ~ h a}^{-\mathbf{1}}\right)$} \\
\hline Variety & $10 \mathrm{~cm}$ & $15 \mathrm{~cm}$ & $20 \mathrm{~cm}$ & Mean & $10 \mathrm{~cm}$ & $15 \mathrm{~cm}$ & $20 \mathrm{~cm}$ & Mean \\
\hline Kamini & 915 & 1001 & 1049 & 988 & 3447 & 2771 & 3101 & 3106.2 \\
\hline Ketaki & 960 & 983 & 1091 & 1011 & 2883 & 3235 & 3293 & 3137.2 \\
\hline Gomati & 982 & 999 & 1112 & 1031 & 2833 & 3305 & 3465 & 3200.8 \\
\hline
\end{tabular}




\begin{tabular}{|c|c|c|c|c|c|c|c|c|}
\hline Mean & 952 & 994 & 1084 & & 3054 & 3104 & 3286 & \\
\hline & & SEM & $\mathrm{CD}(\mathrm{P} \leq 0.05)$ & & & SEM & $\mathrm{CD}(\mathrm{P} \leq 0.05)$ & \\
\hline V & & 32.79 & 128.73 & & & 172.57 & 677.58 & \\
\hline S & & 35.37 & 108.96 & & & 194.94 & 600.65 & \\
\hline VxS & & & & & & & & \\
\hline \multicolumn{2}{|l|}{ V at same level of S } & 59.80 & 765.2 & & & 325.24 & 1079.53 & \\
\hline \multicolumn{2}{|l|}{ S at same level of V } & 61.25 & 880.5 & & & 337.64 & 1040.35 & \\
\hline
\end{tabular}

Table 3: Harvest index and benefit: cost ratio (BC ratio) of cowpea varieties at plant spacings of 10, 15 and $20 \mathrm{~cm}$

\begin{tabular}{|c|c|c|c|c|c|c|c|c|}
\hline & \multicolumn{3}{|c|}{ Harvest Index } & & \multicolumn{3}{|c|}{ Benefit: Cost Ratio } & \\
\hline Variety & $10 \mathrm{~cm}$ & $15 \mathrm{~cm}$ & $20 \mathrm{~cm}$ & Mean & $10 \mathrm{~cm}$ & $15 \mathrm{~cm}$ & $20 \mathrm{~cm}$ & Mean \\
\hline Kamini & 27.4 & 34.8 & 34.4 & 32.2 & 1.112 & 1.228 & 1.422 & 1.254 \\
\hline Ketaki & 35.2 & 30.6 & 34.9 & 33.6 & 1.133 & 1.184 & 1.424 & 1.247 \\
\hline Gomati & 36.4 & 30.9 & 32.2 & 33.2 & 1.134 & 1.187 & 1.417 & 1.246 \\
\hline \multirow[t]{2}{*}{ Mean } & 32.9 & 32.1 & 33.8 & & 1.126 & 1.199 & 1.421 & \\
\hline & & SEM & $\mathrm{CD}(\mathrm{P} \leq 0.05)$ & & & SEM & $\mathrm{CD}(\mathrm{P} \leq 0.05)$ & \\
\hline $\mathrm{V}$ & & 1.75 & 6.87 & & & 0011 & 0.038 & \\
\hline $\mathrm{S}$ & & 2.45 & 7.52 & & & 0.033 & 0.094 & \\
\hline \multicolumn{9}{|c|}{\begin{tabular}{l|l}
$\mathrm{VxS}$ & \\
\end{tabular}} \\
\hline \multicolumn{2}{|c|}{$\mathrm{V}$ at same level of $\mathrm{S}$} & 3.88 & 12.59 & & & 0.044 & 0.132 & \\
\hline \multicolumn{2}{|c|}{$\mathrm{S}$ at same level of $\mathrm{V}$} & 4.23 & 13.03 & & & 0.049 & 0.160 & \\
\hline
\end{tabular}

\section{Conclusion}

The wider plant spacing of $20 \mathrm{~cm}$ x $30 \mathrm{~cm}$, corresponding to a plant population density of $1,66,666$ plants $\mathrm{ha}^{-1}$, may be adopted for the cultivation of the cowpea during rabi in sandy loam soils of Gajapati District, Odisha, as higher cowpea grain yields were obtained compared to the closer and intermediate plant spacings of $10 \mathrm{~cm} \mathrm{x} 30 \mathrm{~cm}$ and $15 \mathrm{~cm}$ x 30 $\mathrm{cm}$, corresponding to population densities of 3,33,333 and 2,22,222 plants ha- ${ }^{-1}$, respectively. The widest plant spacing of $20 \mathrm{~cm}$ had higher benefit-cost ratio (BC ratio) than the closer spacings of 10 and $15 \mathrm{~cm}$ which had similar $\mathrm{BC}$ ratios. Variety x spacing interactions affected BC ratio.

\section{References}

1. Arnon I. Physiological principles of dry land crop production. Physiological Aspect of Dryland Farming, Oxford and IBH Publishing Co. New Delhi, 1975.

2. Farmer Portal, 2018. https:farmer.gov.in/Success Report 2018-19

3. Manjappa K, Nadagowda VB, Palled YB, Kalaghatagi SB, Desai BK. Performance of soybean genotypes with different plant densities under rainfed black soil. Karnataka Journal of Agricultural Sciences. 1994; 7:469471.

4. Natrajaratnam N. Dry matter production and harvest index trends in groundnut (Arachis hypogaea L.). Madras Agricultural Journal. 1979; 66:218-221.

5. Rajesh Kumar Yadav BD, Joon RK, Kumar R. The effect of intra and inter-row spacing and varieties on the seed yield of cowpea. International Journal of Tropical Agriculture. 1997; 15(4):233-236.

6. Shiva Kumar SN. Mishra, Kumar S. Effect of intergenotypic competition on yield assessment at different spacings in cowpea (Vigna unguiculata L. Walp). Indian Journal of Genetics and Plant Breeding. 2002; 62(1):38-41.

7. Shivananda M. Response of cowpea genotype to plant density and fertilizer levels under rainfed vertisols, $\mathrm{PhD}$ Thesis, University of Agriculture Sciences, Dharwad, 2005.

8. Yadav GL. Effect of sowing time, row spacing and seed rate on yield of cowpea under rained condition. Journal of Pulses Research. 2003; 116(2):157-159. 